\title{
Early undernutrition as a cause of changes in phonological processing skills
}

\author{
Patrícia Aparecida Zuanetti ${ }^{1}$ \\ https://orcid.org/0000-0002-9847-2246 \\ Maria Fernanda Laus ${ }^{2}$ \\ https://orcid.org/0000-0002-4947-1642 \\ Sebastião de Sousa Almeida ${ }^{2}$ \\ https://orcid.org/0000-0002-1551-9062 \\ Marisa Tomoe Hebihara Fukuda ${ }^{3}$ \\ https://orcid.org/0000-0003-4360-4552
}

Universidade de São Paulo, Hospital das Clínicas da Faculdade de Medicina de Ribeirão Preto - HCFMRP-USP, Ribeirão Preto, São Paulo, Brasil.

Universidade de São Paulo, Faculdade de Filosofia, Ciências e Letras de Ribeirão Preto - FFCLRP-USP, Ribeirão Preto, São Paulo, Brasil.

Universidade de São Paulo, Faculdade de Medicina de Ribeirão Preto - FMRP-USP, Ribeirão Preto, São Paulo, Brasil.

Institution where the study was conducted: Faculdade de Medicina de Ribeirão Preto

- Universidade de São Paulo - FMRP-USP, Ribeirão Preto, São Paulo, Brasil.

Research support source: Coordenação de Aperfeiçoamento de Pessoal de Nível Superior - CAPES.

Conflict of interests: Nonexistent

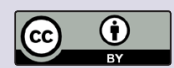

Received on: December 20, 2018 Accepted on: May 10, 2019

Corresponding address:

Patrícia Aparecida Zuanetti

HCRP - USP/CEOF - Centro Especializado

de Otorrinolaringologia e Fonoaudiologia

Avenida Bandeirantes, 3900 - Ribeirão

Preto

CEP: 14048-900 - Ribeirão Preto, São

Paulo, Brasil

E-mail: pati_zua@yahoo.com.br

\section{ABSTRACT}

Purpose: to determine whether undernutrition in the first years of life affects the phonological awareness skills, the phonological working memory and the school performance of children.

Methods: the participants were children with a history of moderate/severe undernutrition during their first years of life (G1) who achieved nutritional recovery $(n=15)$. The performance of $\mathrm{G} 1$ in different cognitive tasks (phonological awareness at the syllable and phoneme level, phonological working memory - repetition of digits and pseudowords, and reading, writing and arithmetic activities) was compared to that of children with school difficulties (G2) $(n=15)$ and without school difficulties (G3) $(n=15)$, all eutrophic ones.

Results: the performance of G1 was worse than that of the other two groups in all tasks evaluated (mean score of G1, G2 and G3 and p-values: phonological awareness: $31,41,57$ - 0.01; repetition of direct order digits: 18, 23, 28 - 0.001; writing: 4, 10, 22 - 0.001; reading: 26, 45, 65-0.001; arithmetic: 4, 7, 11- 0.001).

Conclusion: the results demonstrate that undernutrition affected the cognitive development, causing changes in important cognitive skills for the development of written language.

Keywords: Malnutrition; Child Language; Memory, Short-Term; Learning; Cognition 


\section{INTRODUCTION}

Childhood development consists in an ordered progression of skills (motor, cognitive and personal/ social) originating from the interaction between environmental factors and genetic potential ${ }^{1}$. Through a gradual and increasing process, the initial developmental skills form te basis for subsequent development, including school performance. Risk factors, among them nutritional deficiencies (growth and micronutrient deficits) and the lack of learning opportunities prevent children from achieving their potential for development ${ }^{1,2}$.

Several studies have pointed out that undernutrition, when present during critical growth and brain development periods, severely affects cognition since the brain does not receive the nutrients necessary for its development. The adverse effects of macro- and micronutrient deficiency during childhood may not be fully reversible even after nutritional rehabilitation and continue to affect the various cognitive functions during school years and the quality of life during adulthood ${ }^{3-14}$.

It is known that during the period between the second gestational trimester and the second year of life the Central Nervous System is undergoing accelerated development. Myelinization, neurogenesis and neuronal migration occur during this period ${ }^{15}$ so that nutritional insults during this period represent a high risk factor for the development of the cognitive skills that are essential for written language.

The first studies regarding the cerebral sequelae caused by undernutrition intended to evaluate the brain of children who had died due to this disease. An example is the study by Winick and Rosso ${ }^{16}$ who observed lower RNA and DNA values in relation to weight and protein quantity in the brain of undernourished children compared to control. With the advancement of neurophysiological and chemical techniques, it became possible to determine in more detail the undernutrition-brain relationship in studies using animal models ${ }^{17}$.

The determination of the intelligence quotient (IQ) was the main instrument used to assess the cognitive skills between the 1940 and 1970 decades. In the seventies, the studies started to analyze other aspects in addition to the IQ such as neuropsychomotor development ${ }^{12}$, executive function development ${ }^{6}$, and the development of oral ${ }^{5,8}$ and written language ${ }^{3-5}$. The conclusion of those studies was that severe and chronic undernutrition, especially when occurring at the beginning of life, had significant and lasting implications regarding the development of cognition.
Although some studies have demonstrated a positive relationship between poor school performance and severe undernutrition, few investigations have focused on the development of the cognitive skills needed for the development of written language, among them phonological processing ${ }^{18}$.

Phonological processing refers to the mental operations for information processing based on the phonological structure of oral language, which permit the decoding of words during reading and writing ${ }^{19}$. Skills such as phonological awareness (PA), working memory and rapid access to the lexicon (rapid naming) are the components of phonological processing. The first two tasks have been more extensively studied and are considered to have the highest correlation with the written language ${ }^{19}$.

There is a close relationship between the written language and PA: for the development of written language, children need to perceive that the letters (graphemes) are related to the sound units (phonemes). Thus, it is necessary to be aware of the fact that it is possible to fragment the spoken language and that the segments can be manipulated, involving tasks at the syllabic, intra-syllabic and phonemic level. Working memory is another important component of Phonological Processing that is responsible for the storage and temporary manipulation of the information needed during the execution of complex cognitive tasks ${ }^{20}$. The phonological loop or phonological working memory (PWM), one of the components of working memory, plays an important role in written language by being responsible for the processing of verbal material ${ }^{20}$.

PWM and PA are interdependent. Several clues indicate that PWM may play an important role in PA tasks since during the manipulation of sounds and the resolution of tasks the verbal material must be in the working memory in order to be successfully resolved $^{19}$. However, it has not been defined so far whether the basic deficit that underlies the learning difficulties involves the PWM or the PA, or whether there is a basic change, i.e., whether changes in PWM lead to PA problems or vice-versa, although there is clear evidence of the importance of the integrity of these two factors for the written language $\mathrm{e}^{21-24}$.

Although the literature has well documented the persistent effects of early undernutrition on brain development and its cognitive impacts on the development of children and adolescents, the specific nature of these neurocognitive deficits has not been properly 
evaluated, considering that these studies, in general, only use IQ and schooling levels as parameters for cognitive evaluation. Few studies have been detected that analyzed specific neuropsychological deficits ${ }^{13}$.

On this basis, the objective of the present study was to determine whether moderate or severe undernutrition occurring at an early age causes changes in Phonological Processing skills, thus, impairing the development of written language.

\section{METHODS}

This was a retrospective cohort study approved by the Ethics Committee of the University Hospital, Faculty of Medicine of Ribeirão Preto - USP (protocol number 1924/2009).

\section{Participants}

Forty-five children (21 girls and 24 boys) aged 7 to 10 years were assigned to three groups: $G_{1}(n=15)$ children with moderate or severe undernutrition during the first two years of life (diagnosed by the medical staff of a high complexity hospital) and with a history of nutritional rehabilitation after a period of undernutrition; G2 $(n=15)$ children with no history of undernutrition and with difficulties in academic performance, and G3 $(n=15)$ children with no history of undernutrition with adequate academic performance. The children of the three groups were matched for age, socioeconomic level and type of school institution in the 1:1:1 order, with $\mathrm{G} 1$ children considered as reference.

Exclusion criteria were: children who did not frequent school regularly and children with a diagnosis of genetic syndromes or a history of neurological changes that would impair their cognitive functions, with peripheral audiological changes (hearing loss or changes in the middle ear), and with a history of rehabilitation involving any cognitive skill.

Inclusion criteria for G1 were a history of early childhood undernutrition and nutritional recovery. The children had to be monitored by a medical and nutritionist team at the outpatient clinics of a tertiary care hospital. Inclusion criteria for G2 and G3 were the absence of a low weight history or undernutrition and appropriate development for written language for G3 children.

\section{Materials and procedures}

A total of 584 medical records of children seen at a high complexity hospital were first analyzed in order to select children that would meet the criteria for inclusion in the study as part of G1. Of the 79 children who met the criteria, only 15 fully adhered to the present study.

G2 and G3 children were students enrolled in the public education network. They were selected on the basis of anamnesis of their parents involving questions related to the development of the child and his medical history.

All participants in the present study were submitted to the following procedures:

a) Peripheral auditory evaluation: tone threshold audiometry was applied using a Madsen Electronics audiometer model Midimate 622. The procedure consisted of a threshold study in air conduction (frequencies of 250 to $8000 \mathrm{~Hz}$ ). A Madsen Electronics instrument model Zodiac 901 was used to trace the tympanometric curve for the assessment of the middle ear. These two exams were used in order to apply the exclusion criteria (presence of hearing loss);

b) Evaluation of nutritional status: The past nutritional status of $\mathrm{G} 1$ was diagnosed using the Z-score for Weight/Age (W/A) as an indicator. The Z-score for Body Mass Index (BMI) for age was used as an indicator for the anthropometric assessment of all children (G1, G2 and G3). As recommended by the World Health Organization $(\mathrm{WHO})^{25}$, a Z-score of less than 2 is classified as undernutrition. The indicators were calculated and analyzed by a professional nutritionist using the Epi Info software. The anthropometric measurements (weight and height) were obtained using the following procedures: Body weight (W) was measured in $\mathrm{kg}$ on a Bal-Isopa TecLine digital scale with $0.1 \mathrm{~kg}$ resolution. The procedure was performed in the morning, with the subjects fasting, wearing light clothing and no shoes and having voided their bladder. Height $(\mathrm{H})$ : The participants stood in an erect position, with the head on a vertical plane, wearing no shoes, with their feet joined and resting their back, buttocks and heels against the wall. Their height was marked on the wall and a measuring tape with $1 \mathrm{~cm}$ graduation was used to determine the value in $\mathrm{cm}$.

c) Evaluation of Academic Performance by the Student Performance Test (SPT) ${ }^{26}$ for assignment to G2 and G3: The instrument consists of three subtests: writing (writing one's own name and separate words presented in the form of 
dictation - a maximum of 35 points), arithmetic (solution of problems in an oral manner and arithmetic operation in writing - a maximum of 38 points), and reading (recognition of words out of context - a maximum of 70 points). Crude scores were obtained for each task using this test and each child was classified as having adequate or inadequate school performance based on the standardization by age offered by the test itself.

d) Evaluation of Phonological Awareness: an Instrument of Sequential Evaluation (CONFIAS) ${ }^{27}$ consisting of two parts. The first assesses syllabic awareness (synthesis, segmentation, identification of the initial syllable, of rhymes and of the medial syllable; exclusion and transposition) and the second assesses phonemic awareness (production of a word that starts with the given sound, identification of the initial phoneme, identification of the final phoneme, exclusion, synthesis, segmentation, transposition). All children gave oral responses. The child received 1 point for each correct answer and 0 for each error.

e) Evaluation of Phonological Working Memory (PWM): by means of Subtest 5 of auditory sequential memory of the Illinois Test of Psycholinguistic Abilities (ITPA) ${ }^{28}$. The test consists of 21 digit sequences ranging from two to seven digits arranged in increasing order of digit number to be presented. The child should repeat the sequence presented in the direct order. For this task, the child is allowed two attempts, with 2 points being attributed to a correct answer in the first attempt and 1 point in the second attempt. The maximum score of the test can be 42 points. PWM was also assessed by the Children's Test of Nonword Repetition (RPSS) ${ }^{29}$. This test consists of the repetition of thirty nonwords organized into seven lists varying by number of syllables (one to three syllables). All nonwords consisted of simple syllabic structures (consonant-vowel - CV). One point was attributed to each correct repetition (a maximum of 30 points)

\section{Statistical analysis}

Data were analyzed statistically by the KruskalWallis test and repeated measures MANOVA. The Kruskal-Wallis test was used to determined differences between the three groups (G1, G2 and G3) in the scores for the following tasks: school performance (SPT), phonological memory (ITPA and RPSS- total score), and phonological awareness (CONFIAS). Repeated measures MANOVA was used for a detailed analysis of the RPSS test, i.e., for the determination of possible inter- and intragroup differences in the repetition of nonwords of different extensions (1-6 syllables). The level of significance was set at $a=0.05$ for both tests. When the null hypothesis was rejected ( $p$-value $<0.05$ ), a post-test was applied in order to determine where the difference was located. The post-test used was the Kruskal-Wallis multiple comparisons test, which defined between which groups there was a difference.

\section{RESULTS}

The data regarding the history of undernutrition of G1 are listed in Table 1. All children had experienced a state of moderate or severe undernutrition before 2 years of age even though there were variations regarding the Z-score for W/A. There was also variation in the time during which the child continued to be undernourished (between 0.1 and 1.4 years). 
Table 1. Data (in years) related to the history of undernutrition of G1

\begin{tabular}{cccc}
\hline Child & Age during undernutrition & Duration of undernutrition & Z-score for W/A \\
\hline 01 & 1.1 & 1.1 & -43.15 \\
02 & 0.7 & 0.8 & -6.34 \\
03 & 0.4 & 1.0 & -3.98 \\
04 & 0.5 & 1.4 & -6.84 \\
05 & 0.1 & 1.5 & -5.81 \\
06 & 0.1 & 0.1 & -3.81 \\
07 & 0.1 & $<0.1$ & -3.27 \\
08 & 0.1 & 0.2 & -2.38 \\
09 & 0.4 & 0.11 & -4.6 \\
10 & 1.3 & 0.1 & -3.54 \\
11 & 0.5 & 0.3 & -11.21 \\
12 & 0.1 & 1.1 & -2.96 \\
13 & 0.6 & 1.0 & -4.54 \\
14 & 1.7 & 0.10 & -5.81 \\
15 & 0.3 & 0.10 & -2.26 \\
\hline
\end{tabular}

$\mathrm{W} / \mathrm{A}=$ weight for age

The SPT was used to determine academic performance. The mean scores obtained for each group in the different tasks are listed in Table 2. G2 scores were significantly lower than G3 scores according to the criterion used for group classification. However, a result obtained by G1 in this task should be emphasized: undernourished children also obtained significantly lower scores than G3 for all tasks, but obtained even lower scores regarding writing, with values also lower than those of G2.

Table 2. Mean performance scores for the study groups in the different tasks of the School Performance Test analyzed by the KruskalWallis and Multiple Comparison tests $(\alpha=0.05)$

\begin{tabular}{|c|c|c|c|}
\hline & Mean score & $\mathrm{p}$-value & Post-test result \\
\hline \multirow[t]{3}{*}{ Writing } & $\mathrm{G} 1=04.7$ & $>0.001^{*}$ & $\mathrm{G} 1 \neq \mathrm{G} 3$ \\
\hline & $\mathrm{G} 2=10.2$ & & $\mathrm{G} 1 \neq \mathrm{G} 2$ \\
\hline & $\mathrm{G} 3=22.3$ & & $\mathrm{G} 2 \neq \mathrm{G} 3$ \\
\hline \multirow[t]{3}{*}{ Arithmetic } & $\mathrm{G} 1=04.7$ & $>0.001^{*}$ & $\mathrm{G} 1 \neq \mathrm{G} 3$ \\
\hline & $\mathrm{G} 2=07.3$ & & $\mathrm{G} 1 \neq \mathrm{G} 2$ \\
\hline & $\mathrm{G} 3=11.9$ & & $\mathrm{G} 2 \neq \mathrm{G} 3$ \\
\hline \multirow[t]{3}{*}{ Reading } & $\mathrm{G} 1=26.7$ & $>0.001^{*}$ & $\mathrm{G} 1=\mathrm{G} 2$ \\
\hline & $\mathrm{G} 2=45.1$ & & $\mathrm{G} 1 \neq \mathrm{G} 3$ \\
\hline & $\mathrm{G} 3=65.2$ & & $\mathrm{G} 2 \neq \mathrm{G} 3$ \\
\hline \multirow[t]{3}{*}{ SPT (total) } & $\mathrm{G} 1=39.6$ & $>0.001^{*}$ & $\mathrm{G} 1=\mathrm{G} 2$ \\
\hline & $\mathrm{G} 2=62.6$ & & $\mathrm{G} 1 \neq \mathrm{G} 3$ \\
\hline & $\mathrm{G} 3=94.5$ & & $\mathrm{G} 2 \neq \mathrm{G} 3$ \\
\hline
\end{tabular}

* significant difference 
The results regarding PWM tests are presented below. Regarding RPSS (Figure 1), an extension effect was observed in all groups. For the repetition of 1 to 2 syllables, all groups showed a similar performance, i.e., the children had no difficulty in retaining short phonological information. However, starting with stimuli of 3 syllables, G1 showed a significantly lower score than the remaining groups. With stimuli of 4 syllables G2 also showed a fall in performance, becoming similar to G1. This result indicates that children with deficits in academic performance are less efficient in retaining phonological stimuli than children without such deficits. The performance of G3 was reduced only starting from 5 syllables. Regarding the ITPA, G1 showed the worst performance $($ mean $=18.7$; standard error $=2.6$ ), which was significantly inferior to that of G2 (mean = 23; standard error $=1.6$ ) and G3 (mean $=28.8$; standard error $=2.8)(p-0.001)$.

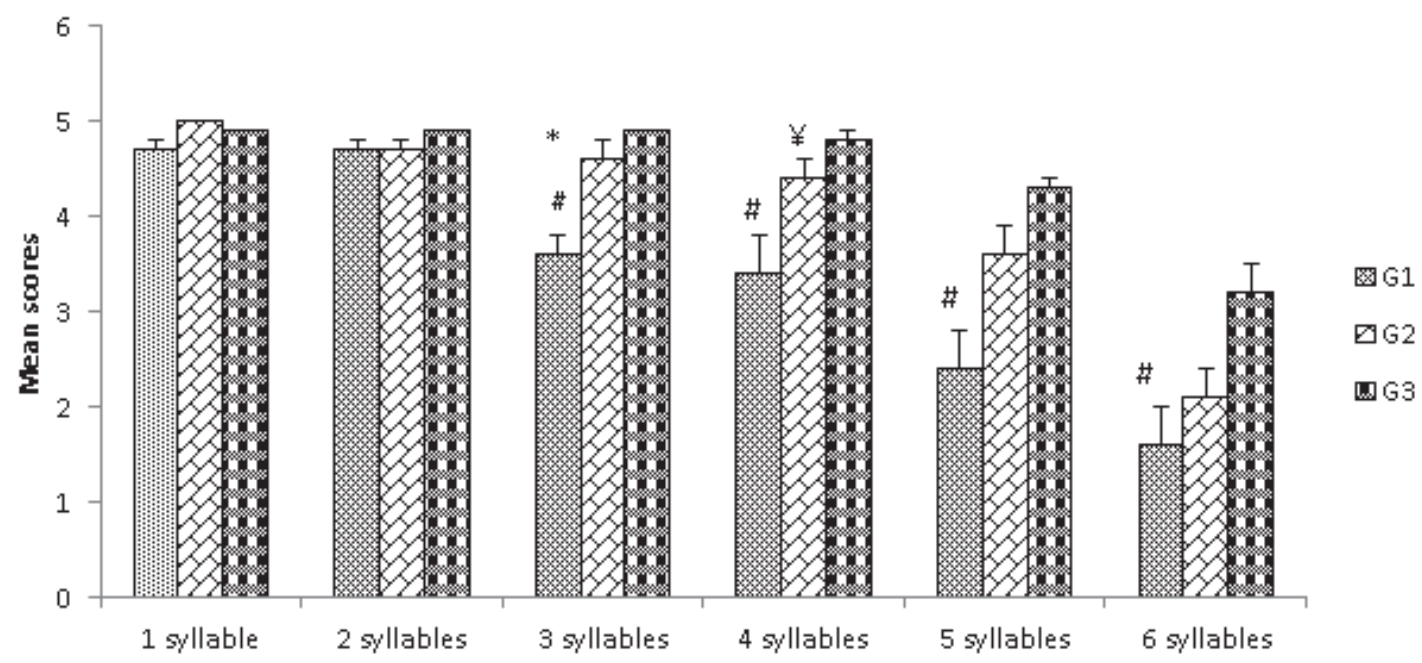

Figure 1. Mean values obtained in the RPSS test. * significant difference between G1 and G2, \# significant difference between G1 and G3, and $¥$ significant difference between G2 and G3

The results of the Phonological Awareness test (CONFIAS) - syllabic level - - (Table 3) demonstrated greater difficulty of $\mathrm{G} 1$ and $\mathrm{G} 2$ in the tasks of rhyme production, syllabic exclusion and syllabic transposition compared to G3. G1 also showed a poorer performance than $\mathrm{G} 3$ in the rhyme task. Regarding the Phonemic Level (Table 3), G1 obtained significantly lower scores than $\mathrm{G} 3$ in the synthesis, segmentation and phonemic transposition tasks, and $\mathrm{G} 1$ and $\mathrm{G} 2$ differed only in the task of word production from a phoneme. This result indicates that undernourished children have a poorer performance than normal weight children with difficulties in academic performance. The general performance differed between $\mathrm{G} 1$ and G2 in relation to: G3 at all levels (syllabic, phonemic and total). And when comparing G1 and G2, it can be seen that $\mathrm{G} 1$ children had significantly lower scores in tasks of syllabic levels or when phonological awareness as a whole was considered. 
Table 3. Mean scores obtained by the 3 groups in the CONFIAS tasks - syllabic and phonemic level, analyzed by the Kruskal-Wallis test and by the Multiple Comparisons test $(\alpha=0.05)$

\begin{tabular}{|c|c|c|c|c|c|c|c|}
\hline Syllabic level & Mean Score & $\mathrm{p}$-value & $\begin{array}{c}\text { Post-hoc } \\
\text { result }\end{array}$ & $\begin{array}{c}\text { Phonemic } \\
\text { level }\end{array}$ & Mean Score & $\mathrm{p}$-value & Post-hoc result \\
\hline \multirow{3}{*}{ Syllable Síynthesis } & $\mathrm{G} 1=3.4$ & 0.051 & & \multirow{3}{*}{$\begin{array}{l}\text { Phonemic } \\
\text { production }\end{array}$} & $\mathrm{G} 1=2.1$ & $0.02^{*}$ & $\mathrm{G} 1 \neq \mathrm{G} 2$ \\
\hline & $\mathrm{G} 2=3.9$ & & & & $\mathrm{G} 2=3.2$ & & $\mathrm{G} 1=\mathrm{G} 3$ \\
\hline & $\mathrm{G} 3=4.0$ & & & & $\mathrm{G} 3=3$ & & $\mathrm{G} 2=\mathrm{G} 3$ \\
\hline \multirow{3}{*}{ Syllable Segmentation } & $\mathrm{G} 1=3.6$ & 0.052 & & \multirow{3}{*}{$\begin{array}{l}\text { Identification } \\
\text { of the initial } \\
\text { phoneme }\end{array}$} & $\mathrm{G} 1=2$ & $0.001^{*}$ & $\mathrm{G} 1=\mathrm{G} 2$ \\
\hline & $\mathrm{G} 2=3.9$ & & & & $\mathrm{G} 2=3.2$ & & $\mathrm{G} 1 \neq \mathrm{G} 3$ \\
\hline & $\mathrm{G} 3=4.0$ & & & & $\mathrm{G} 3=3.6$ & & $\mathrm{G} 2=\mathrm{G} 3$ \\
\hline \multirow{3}{*}{$\begin{array}{l}\text { Identification of the } \\
\text { initial syllable }\end{array}$} & $\mathrm{G} 1=2.6$ & 0.051 & & \multirow{3}{*}{$\begin{array}{l}\text { Identification } \\
\text { of the final } \\
\text { phoneme }\end{array}$} & $\mathrm{G} 1=1.4$ & $>0.001^{*}$ & $\mathrm{G} 1=\mathrm{G} 2$ \\
\hline & $\mathrm{G} 2=3.2$ & & & & $\mathrm{G} 2=1.2$ & & $\mathrm{G} 1 \neq \mathrm{G} 3$ \\
\hline & $\mathrm{G} 3=3.7$ & & & & G3 $=3.1$ & & $\mathrm{G} 2 \neq \mathrm{G} 3$ \\
\hline \multirow{3}{*}{$\begin{array}{l}\text { Identificacation of a } \\
\text { rhyme }\end{array}$} & $\mathrm{G} 1=2.4$ & $0.01 *$ & $\mathrm{G} 1=\mathrm{G} 2$ & \multirow{3}{*}{$\begin{array}{l}\text { Exclusion of } \\
\text { phonemes }\end{array}$} & $\mathrm{G} 1=1.4$ & $0.002^{\star}$ & $\mathrm{G} 1=\mathrm{G} 2$ \\
\hline & $\mathrm{G} 2=3.0$ & & $\mathrm{G} 1 \neq \mathrm{G} 3$ & & $\mathrm{G} 2=1.4$ & & $\mathrm{G} 1 \neq \mathrm{G} 3$ \\
\hline & $\mathrm{G} 3=3.6$ & & $\mathrm{G} 2=\mathrm{G} 3$ & & $\mathrm{G} 3=3.5$ & & $\mathrm{G} 2 \neq \mathrm{G} 3$ \\
\hline \multirow{3}{*}{ Production of words } & $\mathrm{G} 1=2.6$ & 0.12 & & \multirow{3}{*}{$\begin{array}{l}\text { Phonemic } \\
\text { synthesis }\end{array}$} & $\mathrm{G} 1=1.4$ & $0.007^{\star}$ & $\mathrm{G} 1=\mathrm{G} 2$ \\
\hline & $\mathrm{G} 2=3.6$ & & & & $\mathrm{G} 2=1.8$ & & $\mathrm{G} 1 \neq \mathrm{G} 3$ \\
\hline & $\mathrm{G} 3=3.6$ & & & & $\mathrm{G} 3=2.8$ & & $\mathrm{G} 2=\mathrm{G} 3$ \\
\hline \multirow{3}{*}{$\begin{array}{l}\text { Identification of a } \\
\text { mesial syllable }\end{array}$} & $\mathrm{G} 1=1.2$ & $>0.001^{*}$ & $\mathrm{G} 1 \neq \mathrm{G} 2$ & \multirow{3}{*}{$\begin{array}{l}\text { Phonemic } \\
\text { segmentation }\end{array}$} & $\mathrm{G} 1=1.8$ & $0.002^{*}$ & $\mathrm{G} 1=\mathrm{G} 2$ \\
\hline & $G 2=2.4$ & & $\mathrm{G} 1 \neq \mathrm{G} 3$ & & $\mathrm{G} 2=2.9$ & & $\mathrm{G} 1 \neq \mathrm{G} 3$ \\
\hline & $\mathrm{G} 3=3.5$ & & $\mathrm{G} 2 \neq \mathrm{G} 3$ & & $\mathrm{G} 3=0.8$ & & $\mathrm{Ga}=\mathrm{G} 3$ \\
\hline \multirow{3}{*}{ Production of a rhyme } & $\mathrm{G} 1=0.8$ & $>0.001^{*}$ & $\mathrm{G} 1=\mathrm{G} 2$ & \multirow{3}{*}{$\begin{array}{l}\text { Phonemic } \\
\text { transposition }\end{array}$} & $\mathrm{G} 1=0.1$ & 0.051 & \\
\hline & $\mathrm{G} 2=1.2$ & & $\mathrm{G} 1 \neq \mathrm{G} 3$ & & $\mathrm{G} 2=0.4$ & & \\
\hline & $\mathrm{G} 3=2.9$ & & $\mathrm{G} 2 \neq \mathrm{G} 3$ & & $\mathrm{G} 3=1.3$ & & \\
\hline \multirow{3}{*}{ Exclusion of a Syllable } & $\mathrm{G} 1=2.7$ & $>0.001^{*}$ & $\mathrm{G} 1=\mathrm{G} 2$ & \multirow{3}{*}{$\begin{array}{c}\text { Total phonemic } \\
\text { Level }\end{array}$} & $\mathrm{G} 1=10.4$ & $>0.001^{*}$ & $\mathrm{G} 1=\mathrm{G} 2$ \\
\hline & $\mathrm{G} 2=4.2$ & & $\mathrm{G} 1 \neq \mathrm{G} 3$ & & $\mathrm{G} 2=14$ & & $\mathrm{G} 1 \neq \mathrm{G} 3$ \\
\hline & $\mathrm{G} 3=7.1$ & & $\mathrm{G} 2 \neq \mathrm{G} 3$ & & $\mathrm{G} 3=21.4$ & & $\mathrm{G} 2 \neq \mathrm{G} 3$ \\
\hline \multirow{3}{*}{ Syllabic Transposition } & $\mathrm{G} 1=1.0$ & $>0.001^{*}$ & $\mathrm{G} 1=\mathrm{G} 2$ & \multirow{3}{*}{$\begin{array}{l}\text { Total CONFIAS } \\
\text { test }\end{array}$} & $\mathrm{G} 1=31.1$ & $>0.01^{*}$ & $\mathrm{G} 1 \neq \mathrm{G} 2$ \\
\hline & $\mathrm{G} 2=2.0$ & & $\mathrm{G} 1 \neq \mathrm{G} 3$ & & $\mathrm{G} 2=41.9$ & & $\mathrm{G} 1 \neq \mathrm{G} 3$ \\
\hline & $\mathrm{G} 3=3.2$ & & $\mathrm{G} 2 \neq \mathrm{G} 3$ & & $\mathrm{G} 3=57.5$ & & $\mathrm{G} 2 \neq \mathrm{G} 3$ \\
\hline \multirow{3}{*}{ Total syllabic Level } & G1 $=20$ & $>0.001^{*}$ & $\mathrm{G} 1 \neq \mathrm{G} 2$ & & & & \\
\hline & $\mathrm{G} 2=27.9$ & & $\mathrm{G} 1 \neq \mathrm{G} 3$ & & & & \\
\hline & $\mathrm{G} 3=35.4$ & & $\mathrm{G} 2 \neq \mathrm{G} 3$ & & & & \\
\hline
\end{tabular}

* significant difference

\section{DISCUSSION}

Undernutrition during the first years of life may cause lasting impairments which, in the long term, involve global cognitive changes represented by a lower $\mathrm{IQ}^{4-10,12-14}$ or by difficulties in reading, writing and arithmetic tasks $5,9,13$.

In most cases, the presence of cognitive changes results in impaired quality of life characterized by a reduced socioeconomic level 7 . On this basis, it is important to to understand and intervene in this undernutrition/cognition process since early childhood, minimizing the cognitive and social damage to this population on a short- and long-term basis. In order to implement this intervention it is first necessary to determine which cognitive skills are affected by this condition. Although many studies have investigated the cognition/undernutrition relationship, surprisingly there are no studies elucidating which cognitive 
skills are more specifically affected, with a consequent impairment of the organization of remediation measures.

In agreement with world rates about the effects of undernutrition on academic performance, the present study demonstrated that $80 \%$ of children with a history of undernutrition had an unsatisfactory academic performance. A detailed and qualitative analysis of the medical history of $\mathrm{G} 1$ children indicated that $20 \%$ of those who had no difficulties in academic performance were the children who had suffered moderate/severe undernutrition for a short period of time (less than one month).

Thus, the present study intended to analyze the skills of Phonological Processing in children with a history of undernutrition (G1) using PA and PWM tasks, which are directly related to reading/writing processing.

The first result calling our attention was the score obtained by $\mathrm{G} 1$ in the Writing tasks of SPT compared to the remaining groups. Although G2 obtained low scores characterizing weak academic performance, the G1 score was significantly lower than these. This result demonstrates the severe impairment of the skills involved in written language caused by undernutrition and shows that this negative impact may be more determinant than other possible factors regarding poor school performance. Thus, analysis of the performance in PA and PWM tasks may provide information that would clarify in what way undernutrition affects the writing capacity of these children. Writing is considered to be one of the more complex skills to learn because it involves several cognitive functions ${ }^{30,31}$. Among them, $\mathrm{PWM}^{32}$ plays a primordial role since it permits the recovery and maintenance of words, ideas, linguistic chains and grammar rules, in addition to monitoring and controlling irrelevant concurrent information, an essential event in typical situations of daily writing. Thus, writing in a more efficient manner is associated with a better management of PWM resources ${ }^{33}$.

The results of PWM tasks revealed changes of fundamental importance for the clarification of the greater writing difficulties of $\mathrm{G} 1$, especially when the task involved the repetition of nonwords. The children with a history of undernutrition were able to repeat efficiently only nonwords of up to two syllables, whereas G2 was as efficient as G3 in the repetition of up to three stimuli. Nonword repetition is considered to be a complex task which is important for the assessment of PWM, since in the repetition of this stype of stimulus here is no intervention of lexical, semantic or syntactic aspects for the storage of information ${ }^{34}$. The positive relationship between PWM and the written language has been pointed out in several studies and confirmed by the present one since the worst PWM performance was detected in children with school difficulties (G1 and G2).

Regarding PA, the other component of phonological processing, we also observed a difference in total performance in tasks of syllabic level between the three groups. Although G1 showed impairment of performance similar to that of G2 in most tasks, the analysis of general performance demonstrated that the children exposed to undernutrition performed in an even worse manner at the general syllabic level when compared to children with poor academic performance (G2). At the phonemic level, considered to be the most complex ${ }^{35,36}$, the performance of $\mathrm{G} 1$ and $\mathrm{G} 2$ was similarly inferior to that of G3.

We detected no studies investigating PA development in children with a history of undernutrition. The change in this skill observed in the present study contributed to all other results that demonstrated the difficulties in the development of written language among children with early age undernutrition. PA is one of the more important components of the development of reading and writing capacity, which refers to the ability to detect and manipulate the sound structure of words regardless of their menaing ${ }^{16}$.

PWM and PA skills are positively related to auditory processing skills since, in order to process the sounds of speech phonologically it is first necessary to interpret them ${ }^{37,38}$. The auditory pathways of children with a history of undernutrition exhibit a delay in the myelinization process of the auditory pathways. As a consequence, there is a delayed maturation of the auditory pathways represented by an increased latency of I and $V$ waves in the brain stem auditory potentia| ${ }^{39,40}$. Alterations have also been detected in children with a history of undernutrition during evaluation of the auditory pathways (central auditory processing tests) ${ }^{11}$.

\section{CONCLUSION}

The present study demonstrated that the condition of severe undernutrition, when present at an early age, is an important variable that interferes with the development of the cognitive skills necessary for the acquisition of written language (phonological awareness and working memory), resulting in poor school performance. In the phonological awareness task, children with a history of undernutrition were unable to solve 
tasks that involved phonemes, rhymes or more complex tasks at the syllabic level. Regarding their performance in phonological working memory, these children successfully repeated only nonwords of 2 syllables and their performance in the digit repetition task in direct order was inferior to that of the other groups. In addition to being inferior to control children (normal weight children with good school performance), children with a history of undernutrition were also inferior to their peers classified within normal weight but with poor school performance.

\section{REFERENCES}

1. Black MM, Pérez-Escamilla R, Rao SF. Integrating nutrition and child development interventions: scientific basis, evidence of impact, and implementation considerations. Adv Nutr. 2015;6(6):852-9. DOI: 10.3945/an.115.010348

2. Grantham-McGregor S, Cheung YB, Cueto S, Glewwe P, Richter L, Strupp B. Developmental potential in the first 5 years for children in developing countries. Lancet. 2007;369:60-70. DOI: 10.1016/S0140-6736(07)60032-4

3. Ivanovic DM, Leiva BP, Perez HT, Inzunza NB, Almagia AF, Toro TD et al. Long-term effects of severe undernutrition during the first year of life on brain development and learning in chilean high-school graduates. Nutrition. 2000;16(1112):1056-63. DOI: 10.1016/S0899-9007(00)00431-7

4. Ivanovic DM, Leiva BP, Perez HT, Almagia AF, Toro TD, Urrutia MS et al. Nutritional status, brain development and scholastic achievement of chilean high-school graduates from high and low intellectual quotient and socio-economic status. Br J Nutr. 2002;87(1):81-92. DOI: 10.1079/ BJN2001485

5. Liu J, Raine A, Venables PH, Dalais C, Mednick AS. Malnutrition at age 3 years and lower cognitive ability at age 11 years. Arch Pediatr Adolesc Med. 2003;157(6):593-600. DOI: 10.1001/ archpedi.157.6.593

6. Galler JR, Bryce CP, Zichlin ML, Fitzmaurice G, Eaglesfield GD, Waber DP. Infant malnutrition is associated with persisting attention deficits in middle adulthood. J Nutr. 2012;142(4):788-94. DOI: 10.3945/jn.111.145441

7. Galler JR, Bryce C, Waber DP, Zichlin ML, Fitzmaurice GM, Eaglesfield D. Socioeconomic outcomes in adults malnourished in the first year of life: a 40-year study. Pediatrics. 2012;130(1):e1-7. DOI: 10.1542/peds.2012-0073.

8. Nassar MF, Shaaban SY, Nassar JF, Younis NT, Abdel-Mobdy AE. Language skills and intelligence quotient of protein energy malnutrition survivors. J Trop Pediatr. 2012;58(3):226-30. DOI: 10.1093/ tropej/fmr081

9. Ampaabenga SK, Tanb CM. The long-term cognitive consequences of early childhood malnutrition: the case of famine in Ghana. J Health Econ. 2013;32(6):1013-27. DOI: 10.1016/j. jhealeco.2013.08.001

10. Sandjaja Poh BK, Rojroonwasinkul N, Nyugen BKL, Budiman B, Ng LO, Soonthorndhada K et al. Relationship between anthropometric indicators and cognitive performance in southeast asian school-aged children. Br J Nutr. 2013;110(3):S57-64. DOI: $10.1017 /$ S0007114513002079

11. Zuanetti PA, Laus MF, Anastasio ART, Almeida SS, Fukuda MTH. Audiometric thresholds and auditory processing in children with early malnutrition: a retrospective cohort study. Sao Paulo Med J. 2014;132(5):266-72. DOI: 10.1590/1516-3180.2014.1325686

12. Hamadani JD, Tofail F, Huda SN, Alam DS, Ridout DA, Attanasio $O$ et al. Cognitive deficit and poverty in the first 5 years of childhood in Bangladesh. Pediatrics. 2014;134(4):e1001-8. DOI: 10.1542/ peds.2014-0694

13. Waber DP, Bryce CP, Girard JM, Zichlin M, Fitzmaurice GM, Galler JR. Impaired IQ and academic skills in adults who experienced moderate to severe infantile malnutrition: a forty-year study. Nutr Neurosci. 2014;17(2):58-64. DOI: 10.1179/1476830513Y.0000000061

14. Gashu D, Stoecker BJ, Bougma K, Adish A, Haki GD, Marquis GS. Stunting, selenium deficiency and anemia are associated with poor cognitive performance in preschool children from rural Ethiopia. Nutrition Journal. 2016;15(38):1-8. DOI: 10.1186/s12937-016-0155-z

15. Morgane PJ, Mokler DJ, Galler JR. Effects of prenatal protein malnutrition on the hippocampal formation. Neurosci Biobehav Rev. 2002;26(4):471-83. DOI: 10.1016/S0149-7634(02)00012-X

16. Morgan KE. The cognitive effects of chronic malnutrition and environment on working memory and executive function in children. Independent Study Project (ISP) Collection. 2015. In: https:// digitalcollections.sit.edu/isp_collection/2053 
17. Laus MF, Ferreira Vales LDM, Costa TMB, Almeida SS. Early postnatal protein-calorie malnutrition and cognition: a review of human and animal studies. Int J Environ Res Public Health. 2011;8(2):590-612. DOI: 10.3390/ijerph8020590

18. Melby-Lervåg $M$, Lyster SAL, Hulme C. Phonological skills and their role in learning to read: a meta-analytic review. Psychol Bull. 2012;138(2):322-52. DOI: 10.1037/a0026744

19. Brandenburg J, Klesczewski J, Schuchardt K, Fischbach A, Büttner G, Hasselhorn M. Phonological processing in children with specific reading disorder versus typical learners: Factor structure and measurement invariance in a transparent orthography. Learn Individ Differ. 2011;21(1):85-95. DOI:10.1016/j.lindif.2010.10.005

20. Baddeley A. Working memory: theories, models, and controversies. Annu Rev Psychol. 2012;63:1-29. DOI: 10.1146/annurev-psych-120710-100422

21. Ziegler JC, Bertrand D, Tóth D, Csépe V, Reis A, Faísca $L$ et al. Orthographic depth and its impact on universal predictors of reading a cross-language investigation. Psychol Sci. 2010;21(4):551-9. DOI: 10.1177/0956797610363406

22. Cárnio MS, Sá BC, Jacinto LA, Soares AJ. Phonological short-term memory and phonological awareness in students from the elementary school. Codas. 2015;27(5):458-63. DOI: 10.1590/2317-1782/20152014163

23. Gathercole SE, Woolgar F, CALM Team, Kievit RA, Astle D, Manly $T$ et al. How common are WM deficits in children with difficulties in reading and mathematics? J Appl Res Mem Cogn. 2016;5(4):384-94. DOI: 10.1016/j. jarmac.2016.07.013

24. Knoop-Van Campen CAN, Segers E, Verhoeven L. How phonological awareness mediates the relation between working memory and word reading efficiency in children with dyslexia. Dyslexia. 2018;24(2):156-69. DOI: 10.1002/dys. 1583

25. World Health Organization - WHO. WHO Child Growth Standards: Growth velocity based on weight, length and head circumference Methods and development. [citado em 2009]. Acessado em: http://apps.who.int/iris/bitstream/ handle/10665/44026/9789241547635_eng. pdf? sequence $=1$ \&isAllowed $=y$

26. Stein LM. SPT - Teste de Desempenho Escolar: manual para aplicação e interpretação. São Paulo: Casa do Psicológolo; 1994.
27. Moojen S, Lamprecht R, Santos RM, Freitas GM, Brodacz R, Siqueira $M$ et al. Consciência Fonológica: Instrumento de Avaliação Sequencial (CONFIAS). São Paulo: Casa do Psicólogo; 2003.

28. Bogossian MADS, Santos MJ. Memória seqüencial auditiva: subteste 5 . In: Teste Illinois de Habilidades Psicolingüísticas (adaptação brasileira). Florianópolis: Tamasa; 1977. P. 61-7.

29. Kessler TM. Estudo da memória de trabalho em pré-escolares [dissertação]. São Paulo (SP): Universidade Federal de São Paulo, Escola Paulista de Medicina; 1997.

30. Hooper SR. The language of written language: an introduction to the special issue. J Learn Disabil. 2002;35(1):2-6. DOI: 10.1177/002221940203500101

31. Stievano $P$, Michetti $S$, McClintock SM, Levi G, Scalisi TG. Handwriting fluency and visuospatial generativity at primary school. Read Writ. 2016;29(7):1497-510. DOI: 10.1007/ s11145-016-9648-6

32. Swanson HL, Berninger VW. Individual differences in children's working memory and writing skill. J Exp Child Psychol. 1996;63(2):358-85. DOI: 10.1006/jecp.1996.0054

33. Olive T. Working memory in writing: empirical evidence from the dual-task technique. Eur Psychol. 2004;9(1):32-42: DOI: 10.1027/1016-9040.9.1.32

34. Gathercole SE. Is nonword repetition a test of phonological memory or long-term knowledge? It all depends on the nonwords. Mem. Cognit. 1995;23(1):83-94.

35. Laing SP, Espeland W. Low intensity phonological awareness training in a preschool classroom for children with communication impairments. J. Commun. Disord. 2005;38(1):65-82. DOI: 10.1016/j. jcomdis.2004.03.009

36. Goswami U. The development of reading across languages. Ann NY Acad Sci. 2008;1145:1-12. DOI: 10.1196/annals.1416.018

37. Moossavi A, Khavarghazalani B, Lotfi $Y$, Mehrkian $S$, Hosseinidastgerdi Z. Auditory working memory span of children with (central) auditory processing disorders and normal children aged 8 to 10 years. JRSR. 2015;2(2):27-30.

38. Ugolini M, Wagley N, Ip k, Hsu LS, Arredondo MM, Kovelman L. In young readers, the left hemisphere supports the link between temporal processing and phonological awareness. J Speech Lang Hear. 2016;19(1):17-26. DOI: 10.1080/2050571X.2015.1101894 
39. Odabas D, Caksen H, Sar S, Tombul T, Kisli M, Tuncer $\mathrm{O}$ et al. Auditory brainstem potentials in children with protein energy malnutrition. Int $\mathrm{J}$ Pediatr Otorhinolaryngol. 2005;69(7):923-8. DOI: 10.1016/j.ijporl.2005.01.034

40. Vandana, Tandon OP. Auditory evoked potential responses in chronic malnourished children. Indian J Physiol Pharmacol. 2006;50(1):48-52. 